1 Institute for Global Health, University College London, London, UK

2 PMNCH

3 The Ministry of Public Service, Gender, Senior Citizens Affairs and Special Programmes of the Republic of Kenya

4 Tremendas Platform

Cite this as: BMJ 2021;375:n2649 http://dx.doi.org/10.1136/bmj.n2649 Published: 1 November 2021

\title{
Adolescents have not been well served by responses to the pandemic and the climate crisis
}

\author{
Tackling climate change and the pandemic are necessary to regain their trust \\ Anthony Costello, ${ }^{1}$ Helen Clark, ${ }^{2}$ Margaret Kobia, ${ }^{3}$ Julieta Martinez ${ }^{4}$
}

The covid-19 pandemic and the response to it have affected the wellbeing of adolescents throughout the world. Isolation from peers and family has had measurable impacts on adolescent mental health. ${ }^{1}$ A poll of 4000 children and young people aged 8 to 24 years across the UK, for example, found that at least a third said they had experienced an increase of mental health and wellbeing issues, including stress, loneliness, and worry. ${ }^{2}$ Adolescents have witnessed stress within their families through bereavement, unemployment, financial and emotional problems, and fear of infection. ${ }^{3}$ Some have been forced to spend more time in abusive situations. The pandemic has disrupted adolescents' education, destroyed many of their dreams, and reinforced social inequalities.

Although the covid-19 pandemic has been, and will continue to be, devastating for many adolescents, the climate crisis dwarfs the pandemic in its scale and implications. As Greta Thunberg has claimed, "our house is on fire." 4 The climate crisis threatens adolescents' biological, emotional, and social development, particularly as they see no end in sight as corporations and governments largely carry on with business as usual. Climate change will increase adolescents' risks of injury, developing asthma, contracting infectious diseases like dengue, and experiencing poor nutrition. Extreme weather events, heat stress, and water insecurity will lead to conflict and forced migration in many countries. Mental health will suffer because of uncertainty and emotional reactions to an unstable climate. ${ }^{5}$

\section{Regaining trust in the pandemic response}

The health policy, medical, and public health communities must take part of the blame for failing to protect adolescents during the pandemic. Global alerts and published science from January 2020 should have been met with action to stop the epidemic in its tracks and suppress local transmission by testing, tracing, and isolating cases and their contacts. Countries that acted quickly to bring the pandemic under control didn't suffer such long national lockdowns and school closures, nor the same scale of economic damage.

Many countries could have made schools safer, ensured proper ventilation in classrooms, invested in new forms of online learning, and preserved bubbles of social contact within lockdowns. Some could have rolled out safe vaccines to children aged 12 and over much earlier rather than sending thousands of children back to school unprotected. Serious threats to vulnerable young people and the evidence on "long covid" have been dismissed. The fears of young people for their families and older relatives were ignored. Through our professional associations and politicians, we can regain the trust of young people by arguing for much stronger public health systems, for support for younger vulnerable groups, and for adolescents and children to be protected however the pandemic progresses.

Vaccination is key. Despite our scientific prowess in producing effective vaccines at speed, the inequitable distribution of vaccines has been shocking. ${ }^{6}$ Less than $2 \%$ of people in many low income countries, and only $5.6 \%$ overall in Africa, have received a single dose; ${ }^{7} 82 \%$ of all vaccines have gone to rich countries. A two tier system has developed where wealthy countries hoard vaccines and low income countries lack access.

A global solution requires sharing of vaccine manufacturing, yet governments and corporations have blocked or not joined efforts to make covid-19 vaccines more widely available through patent waivers and technology transfers. Presidents Biden and Macron and the chiefs of the World Trade Organization and the World Health Organization (WHO) supported negotiation of a patent waiver for covid-19 vaccines and medicines requested by India, South Africa, and Kenya in October 2020. Yet other G7 countries demurred. Africa wants to have covid-19 vaccine production capacity, ${ }^{8}$ but needs knowledge and technology transfer to make that possible. WHO has proposed an mRNA tech transfer hub, similar to the one that brought billions of extra influenza vaccine doses to the world, but big pharma see future profits from the technology for addressing cancer, Ebola, and HIV, and have not joined in. ${ }^{8} 9$ Support must also be mobilised to redistribute one billion vaccine doses from high income to low income countries this year-the failure to do this to date amounts to what former UK prime minister Gordon Brown has called a "moral failure."10

\section{Regaining trust in the response to climate change}

As the Oxford economist Simon Wren-Lewis has said, "The climate crisis is not caused by vague 'human actions'; nor is it a result of some innate aspect of human nature. It is caused by specific investments by specific people in specific things. Change those, and we can change the future." 11

It is not enough for the health community to simply describe climate threats to health. We have known about the problem and the investment required to address it for 30 years. The polluters must pay. Unless we lobby for the urgent action needed to decarbonise 
our economies through measures like carbon taxes, removal of fossil fuel subsidies, deficit financing, and wealth redistribution, today's adolescents will face a highly uncertain future.

The potential for taxes to contribute to decarbonisation is still largely untapped. The poorest people can be protected by cutting taxes on incomes and raising taxes on carbon. Currently, carbon prices remain far below the $\$ 40-80$ per $\mathrm{tCO} 2$ range recommended in 2020 to meet the "well below $2{ }^{\circ} \mathrm{C}$ " temperature goal of the Paris Agreement. ${ }^{1213}$ Governments can protect poorer people through a Green New Deal funded through deficit financing, borrowing more now to protect against much larger environmental costs in future, and redistribution of wealth through taxation. ${ }^{14}$ These three bold moves would help to secure the futures of today's adolescents.

\section{A global summit for adolescents}

In 2023, a Global Forum for Adolescents will be held, where we hope countries will endorse a clear call to action ${ }^{15}$ and commit to investments that can be closely monitored. All countries need stronger public health systems, vaccine equity, social safety nets, protection of education, environmental resilience, and involvement of adolescents in decision making and in finding creative, adaptive solutions to climate change.

COP26, the United Nations' Climate Change Conference, has begun. Country leaders would be wise to heed the call of Olivia's "Fool" in Shakespeare's Twelfth Night: "What's to come is still unsure: In delay there lies no plenty." Whether there is delay or not, it's crucial that we all support adolescents to attain healthy futures-both for themselves and for our planet.

Competing interests:None declared.

1 Creswell C, Shum A, Pearcey S, Skripkauskaite S, Patalay P, Waite P. Young people's mental health during the COVID-19 pandemic. Lancet Child Adolesc Health 2021;5:-7. doi: 10.1016/S2352-4642(21)00177-2. pmid: 34174991

2 Mental health and Covid-19: in our own words. Barnados. 2020. https://www.barnardos.org.uk/sites/default/files/uploads/mental-health-covid19-in-our-own-words-report.pdf

3 Rodriguez T. Impact of the COVID-19 Pandemic on Adolescent Mental Health. Psychiatry Advisor. 30 April 2021. https://www.psychiatryadvisor.com/home/topics/child-adolescent-psychiatry/adolescent-mental-health-issues-are-further-exacerbated-by-the-covid-19-pandemic/

4 Thunberg G. Our house is on fire. Transcript of speech at World Economic Forum, 25 January 2019. lowa State University, Archives of Women's Political Communication. https://awpc.cattcenter.iastate.edu/2019/12/02/address-at-davos-our-house-is-on-fire-jan-25-2019/

5 Watts N, Amann M, Arnell N, etal. The 2020 report of The Lancet Countdown on health and climate change: responding to converging crises. Lancet 2021;397:-70. doi: 10.1016/S0140-6736(20)32290-X. pmid: 33278353

6 Furlong A, Deutsch J. Rich countries look to third shots, poor countries to half-doses in 'two-track' pandemic. Politico. 24 August 2021. https://www.politico.eu/article/coronavirus-vaccine-boostershots-two-track-pandemic/.

7 Our World in Data. Coronavirus vaccinations. https://ourworldindata.org/covid-vaccinations

8 Furlong A. Africa wants to produce a coronavirus vaccine - and Big Pharma's not happy. Politico. 26 July 2021. https://www.politico.eu/article/as-africa-tries-to-tap-promise-of-mrna-vaccinescoronavirus-covid19-pharma-pushes-back/.

9 World Health Organization. Establishment of a COVID-19 mRNA vaccine technology transfer hub to scale up global manufacturing. 16 April 2021. https://www.who.int/news-room/articles-detail/establishment-of-a-covid-19-mrna-vaccine-technology-transfer-hub-to-scale-up-globalmanufacturing

10 Schomberg W. Ex-UK PM Brown accuses West of 'moral outrage' over COVID vaccine stockpiling Reuters. 4September 2021. https://www.reuters.com/world/uk/ex-uk-pm-brown-accuses-westmoral-outrage-over-covid-vaccine-stockpiling-2021-09-04/

11 Lewis S. Let's say it without flinching: the fossil fuel industry is destroying our future. The Guardian. 10 August 2021. https://www.theguardian.com/commentisfree/2021/aug/10/fossil-fuel-companies ipcc-climate-report-governments?CMP=Share_iOSApp_Other

12 Carbon prices now apply to over a fifth of global greenhouse gases. World Bank press release. 25 May 2021. https:/www.worldbank.org/en/news/press-release/2021/05/25/carbon-pricesnow-apply-to-over-a-fifth-of-global-greenhouse-gases

13 Report of the high-level commission on carbon prices. Carbon Pricing Leadership Coalition. https://www.carbonpricingleadership.org/report-of-the-highlevel-commission-on-carbon-prices
14 Wren-Lewis S. Like so much of what this government does, tackling climate change is just for show. Mainly macro. 24 August 2021. https://mainlymacro.blogspot.com/2021/08/like-so-muchof-what-this-government.html

15 Call to Action for Adolescents. https://www.adolescents2030.org/

This is an Open Access article distributed under the terms of the Creative Commons Attribution IGO License (https://creativecommons.org/licenses/by-nc/3.0/igo/), which permits use, distribution, and reproduction for non-commercial purposes in any medium, provided the original work is properly cited. 